This is an Author's Original Manuscript of an article published by Taylor \& Francis Group in Quality in Higher Education on 22 Sep 2014, available online: http://www.tandfonline.com/

Article DOI: $\quad 10.1080 / 13538322.2014 .957944$

\title{
Reinterpreting higher education quality in response to policies of mass education: the Australian experience
}

Tim Pitman

Curtin University, Perth, Australia

This paper explores the relationship between mass education, higher education quality and policy development in Australia in the period 2008-2014, during which access to higher education was significantly increased. Over this time, which included a change of national government, the discursive relationship between mass higher education and higher education quality shifted from conceptualising quality as a function of economic productivity, through educational transformation and academic standards, to market competition and efficiency. Throughout, the student was more often positioned as a servant towards higher education quality, rather than its benefactor.

Keywords: quality in higher education, mass education, academic standards, higher education policy, widening participation

\section{Introduction}

Democratic access to tertiary education is one of the most persistent policy issues in higher education of the last half-century (Martin, 2009). As UNESCO stated more than 40 years ago, "there cannot-or will not-be a democratic and egalitarian relationship between classes divided by excessive inequality in education" (Faure et al., 1972, p. xxvi). During this time we have experienced global shifts from elite to mass and towards universal education (Trow, 2000). For some stakeholders the shift to mass education is central to higher education's future structure, purpose social and economic role (Schuetze \& Slowey, 2002). Yet for others, this shift constitutes "a serious threat to academic standards, [by creating] institutions staffed by less well-educated and less-accomplished teachers, teaching less-able and less well- motivated students" (Trow, 1974, p. 35). It appears that almost invariably, when policies to increase access to higher education are implemented, the relationship between mass education and educational quality is foregrounded (c.f. Whiteford, Shah \& Nair, 2013; Lomas, 2002).

In 2009 in Australia, in line with recommendations of a review of its higher education system, the restriction on student places was removed, creating a demand-driven funding system (Bradley, Noonan, Nugent, \& Scales, 2008). As a result of this policy, targeted university enrolments rose 20\% between 2008 and 2012 (Department of Education, 2012). Concomitantly, higher education debate referenced the 'problem' of "bringing large 
This is an Author's Original Manuscript of an article published by Taylor \& Francis Group in Quality in Higher Education on 22 Sep 2014, available online: http://www.tandfonline.com/

Article DOI: $\quad 10.1080 / 13538322.2014 .957944$

numbers of students into higher education who are often manifestly unready for the level of instruction demanded [leading to the need] to water down curriculum and standards..." (Hawkins \& Neubauer, 2011, p. 11). Academic standards are the cornerstone of any provider and, both in Australia and internationally, the expansion and diversification of higher education has resulted in growing concerns about their quality (Thompson-Whiteside, 2013). This paper analyses how, throughout 2008-2014, various higher education stakeholders reframed their descriptions of higher education quality, in response to new policies of mass education. The analysis of the overarching policy framework, associated political commentary and public submissions made by the sector, provides a greater understanding of how higher education quality is interpreted and reinterpreted by various stakeholders; both to defend their stake in the sector and to respond to changing policies of mass higher education.

\section{A framework for quality in higher education in specific regards to policies for widening participation}

When researching the effect of policies of mass higher education on ideals of higher education quality, it is helpful to understand broader definitions of quality in play. The vagueness of expectations of different stakeholder groups and different points at which quality is defined and assessed means that quality has different meanings for different audiences (Udam \& Heidmets, 2013). Acknowledging this definitional confusion, higher education stakeholders - in particular policymakers - have shifted the focus away from its substance (i.e. what it is) towards its technical implementation (i.e. how to measure it) (Saarinen, 2010). For example, determining the extent to which universities match employers' demand for skilled workers target groups serve a fitness-for-purpose approach to quality in higher education (Kalayci et al., 2012; Vidovich \& Currie, 1998). Since fitnessfor-purpose implies the product fulfils the customers' needs, the case can be made that for the Australian higher education sector, those needs are to educate persons, create and advance knowledge and apply this knowledge for the betterment of society (Department of the Attorney General, 2003). 'Quality as transformation', whereby the student is improved, rather than just served (Harvey \& Green, 1993) is another approach that is sympathetic to the pedagogic processes of higher education. With the development of mass education, both fitness for purpose and transformation offer less problematic approaches to quality for university administrators than, for example, 'quality as excellence' (Lomas, 2002). However stakeholders must negotiate all definitions of quality, not just preferred ones.

How quality in higher education is measured is frequently delineated by spheres of activity; namely at input, process and output (Harvey \& Green, 1993; Saarinen, 2010; Udam \& Heidmets, 2013). This is particularly the case when widening participation is the goal. For example, policymakers may wish to set a target of $X$ number students applying for university (i.e. input); $X \%$ of students passing their studies (process) or $\mathrm{X} \%$ of students finding 
This is an Author's Original Manuscript of an article published by Taylor \& Francis Group in Quality in Higher Education on 22 Sep 2014, available online: http://www.tandfonline.com/

Article DOI: $\quad 10.1080 / 13538322.2014 .957944$

employment within a year of graduation (output). Determining the value for ' $X$ ' reveals three relativities. First, $\mathrm{X}$ can be set at a threshold level; ensuring representation meets a minimum level. Second, a reference value can be used; to ensure that the targeted students make up the same proportion of all students as they do in the wider population. Third, an institutional target can also be used; which is essentially a threshold value set at the institutional level and takes into account specific (e.g. demographic) circumstances at the local level. Institutional targets can therefore be less, more or equal to the sector's threshold target (Martin, 1994). To this should also be added a temporal aspect; for example, the date by which the policy deliverable(s) must be achieved. However higher education quality can also be measured in terms of customer satisfaction (Aldridge \& Rowley, 1998), graduate competencies (Warn \& Tranter, 2001) or wider assessments of the value of the entire higher education 'experience' (Tam, 2001).

\section{Research method}

This method underlying this paper is one of critical discourse analysis, recognising that policy discourse is a social phenomenon, with a particular focus on how power and ideology are revealed in supposedly neutral policy documents (Blommaert \& Bulcaen, 2000; Fairclough, 2003). In relation to education, critical approaches invariably aspire towards a greater understanding of a desired future: for the individual, society, the imagined community that is the nation, and for the global community (Lingard \& Gale, 2007). The 2008 Review of Australian higher education is just such an imagining and so too are the individual institutions' responses, both at the time of the initial review in 2008 and the subsequent re-review of its demand driven component in 2013. The policy discourses being critically analysed were contained in the initial review document (Bradley, et al., 2008), the 37 open submissions made by Australia's public universities in 2008; then the 2013 review and associated 30 open submissions; and the final report and budget response in 2014.

In line with the theme of this paper, the aim of the critical research approach was to examine how certain framings discourses of mass higher education were employed to promote, defend or attack specific discourses of quality in higher education. For example, explication of the fundamental goals of mass higher education illuminated how certain fitness-for-purpose approaches to quality were perceived. Discussion regarding the potential for more student places to allow entry for students without sufficient academic preparation revealed an inputs-based approach to higher education, whereas dialogue surrounding the pastoral care of students using alternative pathways to higher education placed more emphasis on quality assurance processes. Overall, these revelations helped expose the critical (i.e. some values are greater than others) reality of policy design, as opposed to interpretive (i.e. all values are equal) or positivistic (i.e. value-less) realities (Fossey et al., 2002) 
This is an Author's Original Manuscript of an article published by Taylor \& Francis Group in Quality in Higher Education on 22 Sep 2014, available online: http://www.tandfonline.com/

Article DOI: $\quad 10.1080 / 13538322.2014 .957944$

\section{The 2008 Review of Australian higher education: quality through greater participation and productivity}

The 2008 Review of Australian higher education was commissioned by the (then) Labor Federal Government and undertaken by a review panel selected by the same Government. The role of the panel was as an expert adviser, operating within the relevant field of practice (i.e. higher education) and seeking to intersect its professional knowledge with executive power. The language of 'crisis' frequently serves as a potent, discursive policy tool (Lo Bianco, 2001) and the Review prefixed its recommendations accordingly:

The current financial crisis highlights both the speed with which events elsewhere can affect our country and the force with which they can hit our institutions. Only citizens who are resilient, informed, adaptable and confident will manage the consequences of the new global economy with all its opportunities and threats (Bradley, et al., 2008, p. 1).

The notion of government intervention to solve a crisis has a long political history, but its most recent iteration is in the form of neoliberalism (Garrick, 2011). The crisis referred to in the Review was framed as the capacity of the nation to "maintain and enhance global competitiveness and prosperity" (Bradley, et al., 2008, p. 9). The underlying justification for wider participation was presented as the need to address "persistent skills shortages" (Bradley, et al., 2008, p. 17), which itself was evidenced by demand for people with higher education qualifications exceeding supply. Thus, the fundamental definition of a quality higher education sector was one that actualised a knowledge nation towards economic prosperity.

The Review recommended allowing universities to "set their own entry standards and determine which students to enrol" (Bradley, et al., 2008, p. 157). Whilst this potentially compromised the quality (assurance) of the educational experience, by de-homogenising the student body, quality standards would be maintained locally and supported at the sector level by the creation of a quality and standards agency. Here, the quality of the education experience was subsumed under the broader principles of demand and supply. Quality would be measured using the following indicators: student progression and completions rates; post-graduation (i.e. employment and further study) outcomes and student satisfaction surveys (Bradley, et al., 2008, p. 80). A quality higher education sector was therefore defined hierarchically as one that: supplied students and the market with indemand skills (i.e. fitness for purpose); retained and graduated a high proportion of students (i.e. efficiency); and generated positive student feedback (i.e. customer satisfaction).

In response to the Review, the submissions of the public universities overwhelmingly supported the recommendation to widen participation in higher education by creating a 
This is an Author's Original Manuscript of an article published by Taylor \& Francis Group in Quality in Higher Education on 22 Sep 2014, available online: http://www.tandfonline.com/

Article DOI: $\quad 10.1080 / 13538322.2014 .957944$

demand driven system. Increased access was explicitly linked to labour demand and increased productivity; notions that conceptualised quality as fitness-for-purpose:

Broadening higher education participation can be linked to the building of social capital required for Australia's economic development; groups that are underrepresented in higher education are seen as a great pool of Australian talent that cannot be allowed to remain underexploited; and diversity becomes linked with excellence and innovation (University of Southern Queensland, 2008, p. 7)

However whilst acknowledging the legitimacy of market forces in higher education demand and supply, Australia's public universities did not oppose the "distortion" of government funding (Marginson, 2002, p. 419). The concern was, as one institution observed:

Inadequate indexation of Commonwealth Grant Scheme funding to universities is a significant contributor to the shortfall in higher education funding... Universities are labour-intensive organisations... Indexation of operating grants should realistically take into account sector-appropriate salary increases (Monash University, 2008, pp. 6-7).

Given that the majority position was that funding per equivalent full-time-student load was insufficient, it followed for the sector that wider participation would impact on quality higher education processes in a directly proportional relationship. For most universities therefore, individual inputs did not affect higher education quality, but their overall volume did.

Fifteen universities referenced quality as a function of input in another, also oblique manner. In line with classical conceptualisations of movements from elite to mass education (Trow, 1962, 1970, 1974), these institutions pointed to the fact that an associated goal of wider participation was to increase proportional representation from groups of students historically underrepresented in higher education. Since this underrepresentation was in part a function of their socio-economic exclusion from the broader community, it followed for these universities that these students' higher education success was dependent on additional support:

There are still relatively high attrition rates, particularly for commencing students from low socio-economic status (SES) backgrounds - although our analysis shows that students who are supported through formal bridging, enabling and other support programs have a much higher rate of success. How much more could universities do in terms of preparing and, importantly, retaining through to graduation, students from backgrounds not traditionally associated with higher education? (University of Tasmania, 2008, p. 4) 
This is an Author's Original Manuscript of an article published by Taylor \& Francis Group in Quality in Higher Education on 22 Sep 2014, available online: http://www.tandfonline.com/

Article DOI: $\quad 10.1080 / 13538322.2014 .957944$

Therefore, the overall diseconomy of scale problem was exacerbated by a potential disproportionate increase in students "who require special support to enhance their chances of success, [which] consumes resources" (University of Newcastle, 2008, p. 8). Nonetheless, this quality concern was subsumed into the almost universal support the sector gave towards goals of widening participation.

Three universities made specific references which, whilst not attacking goals of wider participation, used negative language in describing the quality of the student intake under policies of mass education. The University of Melbourne noted that wider participation would "benefit students with weaker [emphasis added] Year 12 results" or those who could not "find an institution willing to accept them" (University of Melbourne, 2008, p. 7). The University of Western Australia contextualised what it perceived as the current lack of quality in Australia's higher education system against almost thirty years of policies in pursuit of mass education. It argued:

It is possible this shortcoming is in part a reflection of the way the system has developed since the Dawkins reforms of 1987 which created a 'unified national system'. At that time all our higher education providers became universities; twenty years on, all our universities have now - sadly - become Higher Education Providers (HEPs) in Commonwealth terminology. We believe that in this process something more than elegant nomenclature has been lost principally the characteristics which would elevate our vision to have Australian universities which match the world's best (University of Western Australia, 2008, p. 1)

For its part, the University of Technology, Sydney, observed:

The quality of teaching and learning in Australia... has gone backwards against the rest of the world over the last decade. Because of a student load distribution policy which encourages universities to fill their quotas irrespective of quality or risk penalty (University of Technology Sydney, 2008, p. 1).

Whilst all three responses attacked higher education policy, they employed discourses of quality inputs to do so and in doing so, promoted a narrower vision of higher education quality that focussed on the prior academic ability of the incoming students. In contrast to the majority position of the sector overall, these three universities presented the students themselves and/or the system that attracted 'those types' of students, as a direct threat to higher education quality. This minority position revealed a tension within the sector, where goals of access and equity were "still commonly perceived in many quarters as lowering standards, creating additional burdens on staff and representing a general threat to quality and excellence" (University of Southern Queensland, 2008, p. 7). 
This is an Author's Original Manuscript of an article published by Taylor \& Francis Group in Quality in Higher Education on 22 Sep 2014, available online: http://www.tandfonline.com/

Article DOI: $\quad$ 10.1080/13538322.2014.957944

Thus, the Government defined higher education quality primarily through the sector's ability to provide sufficient quantities of professional workers and legitimated its new policy by identifying a crisis in this respect. In response, the sector adopted approximate definitions of quality, but attempted to reframe the crisis as one of funding, which was detrimental to their attempts to provide appropriate support for learners (i.e. quality though transformation). With only a few exceptions, neither universities nor government identified increased enrolments as a direct threat to higher education quality. In terms of measurement, quality would be evidenced ultimately by hard numbers; namely enrolments, graduates and skilled workers.

\section{The 2013 Review of the Demand driven Funding System: quality as transformation and excellence}

The demand driven aspect of reform initially received bi-partisan support, with the Opposition spokesperson for education stating that the system was a "vast improvement on the centralised, state control model" and arguing that supply and demand always worked better (The Australian, 2011). However throughout 2012-13, faced with a growing budget deficit and a forthcoming election, the Labor Government moved to cut the higher education budget by approximately $\$ 4$ billion. This drew the long-term viability of the demand driven system into doubt, as it required the Government to commit to funding by demand with no pre-determined fiscal limit. Whilst acknowledging the financial implications of this policy, the Minister for Higher Education, Kim Carr, chose to frame the debate in terms of educational quality:

Under this system an extra 190,000 students have studied at university who may not otherwise have done so... That's a tremendous opportunity for working-class students but we have to make sure that across the system quality also remains a priority. I am a very strong believer in equity, but I am also a believer in excellence... So I need to consider whether it is appropriate here to re-examine the growth rates in the university system. (Carr, as quoted in Taylor, 2013)

In 2013, the Labor Government was removed and the newly-elected Coalition Government announced a review of the funding system. Though the issue of fiscal sustainability was included in the scope of the review, the Minister for Education like his predecessor chose to focus instead on the issue of quality. The review, he said, was designed:

To see if that is impacting on quality as some people believe that it has... It's a very important reputation to maintain and the poison that would undermine that reputation would be a diminution in quality... Quality is our watchword... (Pyne, as quoted in Hurst \& Tovey, 2013) 
This is an Author's Original Manuscript of an article published by Taylor \& Francis Group in Quality in Higher Education on 22 Sep 2014, available online: http://www.tandfonline.com/

Article DOI: $\quad$ 10.1080/13538322.2014.957944

The stated purpose of the 2013 Review was to recommend improvements to ensure Australia's higher education sector "better meets its objectives, is efficient, is fiscally sustainable, and supports innovation and competition in education delivery" (Department of Education, 2013). As was the case in 2008, the review panel was notionally independent but selected by the minister and thus perceived as being sympathetic to his policy agenda. Three terms of reference related to the intersection between wider participation and quality. First, the Review sought evidence of the extent to which the system was increasing participation, particularly for students from low socio-economic status backgrounds and rural and regional communities. Second, whether there was evidence of any potential adverse impacts on the quality of teaching and of future graduates. Third, what measures universities were taking "to ensure quality teaching is maintained and enhanced in the demand driven system" (Department of Education, 2013).

Given that the 2008 Review had preferred a fitness-for-purpose approach to quality, it might have been expected that the 2013 Review would attempt to measure performance in this respect. However this was problematic, as the 2013 Review occurred too early for the students enrolled as part of the widening participation agenda to have yet completed their studies, or for empirical data regarding completion rates and supply of skilled workers to be available. Nonetheless, the 2013 Review did also ask universities to address the "meeting the skills needs of the economy" (Department of Education, 2013). Thirty out of 37 public universities made public submissions and of these, eleven universities claimed positive evidence in this respect, either by demonstrating development of new courses targeting "particular skills shortages" (University of Western Sydney, 2013, p. 13) or increased enrolments in "courses aligned with national skill shortage areas" (Flinders University, 2013, p. 5). All thirty universities contextualised their own efforts to widen participation against sector-wide expansion of around 469,000 student places in 2009 to an estimated 577,000 places in 2013 (Department of Education, 2013). Each of the 30 universities supported a continuation of the demand driven system as a mechanism, in the words of one institution, "to increase and broaden access to higher education" (University of Queensland, 2013, p. 1).

As was the case in the Review in 2008, the consensus position of the sector, explicitly stated in 23 out of 30 submissions, was that increased access to higher education had not been detrimental to quality. To support this contention, the sector focussed its attention on two key indicators; namely attrition rates (students dropping out in the first year) and success rates (the ratio of subjects passed to failed):

Key indicators of quality are retention and completion rates... since 2008 retention is stable across the sector and has improved at RMIT. Therefore, there is no evidence to suggest that the system itself has had a significant adverse impact on the quality of learning and teaching (Royal Melbourne Institute of Technology, 2013, p. 5) 
This is an Author's Original Manuscript of an article published by Taylor \& Francis Group in Quality in Higher Education on 22 Sep 2014, available online: http://www.tandfonline.com/

Article DOI: $\quad$ 10.1080/13538322.2014.957944

The official statistics data largely supported this position. For example, from 2009, when universities started accelerating enrolments in line with the widening participation policy, to 2011, the most recent data available prior to the Review being called, more than half of the universities (19 out of 37 ) saw their institutional attrition rate actually improve. Whilst success rates declined in 29 universities they did so on average only by $1.21 \%$, against a backdrop of increases in enrolment of almost 20\% (Department of Education, 2012). Therefore, despite participation widening significantly, attrition rates generally improved and success rates declined little, or not at all. The use of these metrics informed definitions of quality both as transformation (i.e. improving the student) and excellence (i.e. a high standard of constitutive elements). The citation of attrition and success rates also transmitted discourses of quality assurance, being as they were proxies of quality of the educational processes supporting the students.

Whilst no university stated categorically that the efforts to widen participation had adversely affected educational quality, five institutions alluded to the possibility that this might occur. These institutions mostly prosecuted a variance of the diseconomy of scale approach to quality that was a theme of the 2008 Review. One institution warned "The combined absence of price flexibility... has driven research universities to seek volumebased financial sustainability and to cross-subsidise research from education. Both responses threaten quality" (University of Western Australia, 2013, p. 3). Another stated that with Government contributions to higher education well below the OECD average "the demand driven system creates strong incentives for growth in lower cost, moderate quality courses, while severely constraining the ability of universities to offer world class education" (University of Melbourne, 2013, p. 1). Two universities made specific reference to students' prior academic achievement as a concern. As one observed "We do not view [high school achievement] as a definitive measure of academic ability but we do believe it provides a measure of academic preparedness (University of Queensland, 2013, p. 3).

In essence, the 2013 created an environment where universities attempted to address quality discourses spanning two (opposing) governments and agendas. This involved acknowledging both the initial participation and productivity agendas and the new agendas of academic standards and fiscal sustainability. The response of the sector was to place greater attention on the transformative aspects of higher education quality, maximising the relatively limited empirical data available.

\section{The 2014 report and government response: quality through competition}

In April 2014, the Department of Education released its report into the review of higher education. The report's key recommendation was that the demand driven approach to funding not only be maintained but expanded to include sub-bachelor courses and private providers. It advised "greater competition for student enrolments [has] lifted quality" and "in light of the benefits of the demand driven system, there is no persuasive case for the 
This is an Author's Original Manuscript of an article published by Taylor \& Francis Group in Quality in Higher Education on 22 Sep 2014, available online: http://www.tandfonline.com/

Article DOI: $\quad$ 10.1080/13538322.2014.957944

reintroduction of caps" (Kemp \& Norton, 2014, p. iii). The political and rhetorical argument that mass education was compromising quality was therefore unsupported by the Government's own commissioned review. Instead the review proposed an alternative discourse of higher education quality: that of market efficiency. The reviewers argued:

The strength of a demand driven system is in adapting to individual and local needs and circumstances, and not in meeting centrally-determined [equity] targets. Targets create inferior benchmarks for judging the success or failure of the higher education system (Kemp \& Norton, 2014, p. 35)

Under the logic of the market, 'arbitrary' targets were irrelevant since competition would be enough to ensure participation would grow overall. In such an environment, a key metric of higher education quality would be students' satisfaction with teaching. For example, the reviewers highlighted data showing that at the five fastest-growing universities, student satisfaction with teaching improved from 2010 to 2012 and that the sector level, results "steadily improved over time" (Kemp \& Norton, 2014, p. 9). It argued that in a system where demand no longer exceeded supply:

A student who leaves early is two or three years of lost revenue. This is a significant issue for universities and faculties within universities... Bad word-ofmouth reports on teaching and negative student survey results... may also inform the choices of prospective students (Kemp \& Norton, 2014, p. 10).

The report also addressed the political concern regarding 'low-quality' students entering the system by again invoking market discourses of quality. Suggesting that "higher education may not be their best first option", the reviewers proposed extending the demand driven funding system to sub-bachelor places as these courses "can be a more prudent place to start higher education than in a bachelor degree" (Kemp \& Norton, 2014, p. 13). This would also allow more private education providers to enter the market, providing further competition for six and twelve-month diplomas designed to prepare students for tertiary study.

Whilst a market/competition definition of quality did not support the argument that mass education was compromising educational standards, it did provide an alternative avenue for the government to address the fiscal imbalance. The definitive solution for the Government was found in another, wide-ranging review of Commonwealth finances, known as the Commission of Audit, announced by the Federal Treasurer in 2013. The commission's broad mission was to "eliminate wasteful spending" (National Commission of Audit, 2013, p. 1) and in respect of higher education it made three key recommendations. First, to decrease the average proportion of higher education costs paid by the Commonwealth from $59 \%$ to $45 \%$ and increase the student contribution from $41 \%$ to $55 \%$. Second, increasing the interest rate charged to students on the subsequent student loan. Third, "tasking the Minister for 
This is an Author's Original Manuscript of an article published by Taylor \& Francis Group in Quality in Higher Education on 22 Sep 2014, available online: http://www.tandfonline.com/

Article DOI: $\quad 10.1080 / 13538322.2014 .957944$

Education with developing options to increase competition in Australia's education system through a partial or full deregulation of fees for bachelor degrees" (National Commission of Audit, 2014). The Government subsequently delivered its budget in May 2014 and adopted these recommendations in full. Put simply, university students were now required to shoulder a larger proportion of the cost of maintaining Australia's mass higher education system. In respect of deregulating the sector and allowing universities to set their own tuition fees, the education minister highlighted the functions of the global education market and advised:

We must look to how to... protect education quality... Our answer will be, above all, to set our universities free... Respect for the autonomy of universities, and a commitment to quality and deregulation, are at the heart of the approach I have taken to supporting our higher education institutions (Pyne, 2014)

Thus, whereas the higher education review in 2008 understood universities as an instrument for the benefit of the wider economic market, in 2014 these institutions had been repositioned as a market in their own right. Quality would not primarily be measured through 'arbitrary' performance indicators, but determined by customer satisfaction as evidenced through demand.

\section{Conclusion}

In a democratic society, interests are negotiated, resulting in policy outcomes that most stakeholders can more or less live with. Higher education policy is thus a product of compromises and trade-offs (Rizvi \& Lingard, 2011). In negotiating these compromises, higher education stakeholders employ dialogic techniques to strengthen their own position and/or undermine others. In this regard, 'quality' is one of the most potent discursive weapons available for it is a word that has centrality and power, yet ambiguity, in the field of higher education (Lindsay, 1992). As this study has shown, it is a term that has been reinterpreted by various stakeholders to either defend a particular interest or adapt to changes in public policy. The original (2008) review of Australian higher education conceptualised higher education quality as a function of both widening participation and increased economic productivity. As the cost of mass education rose significantly, the Government partly retreated from its original policy position, reframing higher education quality in terms of academic standards and positing mass education as a threat in this regard. The response by the sector was to prioritise the transformative aspects of higher education quality and argue academic standards were not being compromised. The new Government's (2013) review considered the higher education sector a market in and of itself and mobilised discourses of competition and efficiency to delineate quality. Finally, the Government took this recalibrated position on quality and used it to justify a user-pays approach to higher education and placing more of the responsibility for quality in higher education on the student him/herself: both by providing the economic capital to improve 
This is an Author's Original Manuscript of an article published by Taylor \& Francis Group in Quality in Higher Education on 22 Sep 2014, available online: http://www.tandfonline.com/

Article DOI: $\quad 10.1080 / 13538322.2014 .957944$

educational standards, as well as behaving like a consumer in order to encourage universities to improve the quality of their 'product'. Thus, whilst the word 'quality' in higher education has worth, it is meaningless when presented without context. The development, enactment and alteration of higher education policy clearly highlight its malleable and iterative nature. For governments, whilst a strategy of being deliberately non-prescriptive in defining quality can offer advantages in political processes, it opens the door for other policy actors to mobilise the term against itself. This can result in independent but partisan panels making recommendations contrary to governmental goals, as was the case here. However, again leveraging the malleability of the concept of quality on higher education, the government subsequently reinterpreted the idea of quality to reclaim the policy ascendancy.

Much of the fallout from these discursive battles has been felt by the students. Despite diverse definitions there appears strong evidence of a subservient relationship between the student and most conceptualisations of quality in higher education. That is, the student more often serves quality, rather than vice versa. When quality is defined in terms of wider participation and economic productivity then the student becomes the means to the end. When quality is defined as academic standards then it is the student who represents the risk, not the educational processes. And when higher education becomes a market, responsibility is placed on the student to maintain its quality by behaving rationally, as a consumer, and contributing more to its cost. In all cases the student is constituted as a rational agent of choice. Any failings - for example a perceived or real reduction in the quality of higher education - are the failure of the student, not the system (Bansel, 2007; Davies \& Bansel, 2005). There is a seemingly relentless shift to the student, for a larger and larger proportion of the cost of education. The student not only shoulders this burden but also the responsibility for maintaining higher education standards by choosing wisely. It is only when quality is understood as a transformational process that continued resistance, at least by some sections of the higher education sector, is shown towards contemporary policies of mass education.

\section{References}

Aldridge, S., \& Rowley, J. (1998). 'Measuring customer satisfaction in higher education', Quality Assurance in Education, 6(4), 197-204.

Bansel, P. (2007). Subjects of choice and lifelong learning. International Journal of Qualitative Studies in Education, 20(3), 283-300.

Blommaert, J., \& Bulcaen, C. (2000). 'Critical discourse analysis', Annual Review of Anthropology, 29(1), 447-466.

Bradley, D., Noonan, P., Nugent, H., \& Scales, B. (2008). Review of Australian higher education: Final report. Canberra: Department of Education, Employment and Workplace Relations.

Davies, B. \& Bansel, P. (2005) The time of their lives? Academic workers in neoliberal time(s), Sociology of Health Review, 14(1), 47-58. 
This is an Author's Original Manuscript of an article published by Taylor \& Francis Group in Quality in Higher Education on 22 Sep 2014, available online: http://www.tandfonline.com/

Article DOI: $\quad 10.1080 / 13538322.2014 .957944$

Department of Education. (2012). Selected Higher Education Statistics, from http://www.innovation.gov.au/highereducation/HigherEducationStatistics/Statistics Publications/Pages/Students.aspx

Department of Education. (2013). Review of the Demand Driven Funding System Retrieved 6 December, 2013, from http://education.gov.au/review-demand-driven-fundingsystem

Department of the Attorney General. (2003). Higher Education Support Act 2003. Canberra: Australian Government Printing Service.

Fairclough, N. (2003). Analysing discourse : Textual analysis for social research London: Routledge.

Faure, E., Herrera, F., Kaddoura, A., Lopes, H., Petrovsky, A., Rahnema, M., \& Ward, F. (1972). Learning to be: The world of education today and tomorrow. London: UNESCO.

Flinders University. (2013). Submission to the Review of the Demand-Driven Funding System for Higher Education Retrieved 10 February, 2014, from https://submissions.deewr.gov.au/Forms/demand-driven-fundingsystem/pages/index

Fossey, E., Harvey, C., McDermott, F., \& Davidson, L. (2002). Understanding and evaluating qualitative research. Australian and New Zealand Journal of Psychiatry, 36(6), 717732.

Garrick, B. (2011). The crisis discourse of a wicked policy problem: vocational skills training in Australia. Australian Educational Researcher, 38, 401-416.

Harvey, L., \& Green, D. (1993). Defining Quality. Assessment \& Evaluation in Higher Education, 18(1), 9-34. doi: 10.1080/0260293930180102

Hawkins, J. N., \& Neubauer, D. (2011). Access, equity, capacity: Initiating some distinctions. In D. Neubauer \& Y. Tanaka (Eds.), Access, equity, and capacity in Asia-Pacific higher education. New York: Palgrave MacMillan.

Hurst, D., \& Tovey, J. (2013). Christopher Pyne reveals university shake-up. The Sydney Morning Herald, from http://www.smh.com.au/federal-politics/politicalnews/christopher-pyne-reveals-university-shakeup-20130924-2ucag.html

Kalayci, N., Watty, K., \& Hayirsever, F. (2012). Perceptions of quality in higher education: a comparative study of Turkish and Australian business academics,. Quality in Higher Education, 18(2), 149-167.

Kemp, D., \& Norton, A. (2014). Review of the demand driven funding system report. Canberra: Department of Education.

Lindsay, A. (1992). Concepts of quality in higher education. Journal of Tertiary Education Administration, 14(2), 153-163. doi: 10.1080/1036970920140203

Lingard, B., \& Gale, T. (2007). The emergent structure of feeling: What does it mean for critical educational studies and research? Critical Studies in Education, 48(1), 1-23. doi: $10.1080 / 17508480601131456$

Lo Bianco, J. (2001). Policy literacy. Language and Education, 15(2-3), 212-227.

Lomas, L. (2002). Does the development of mass education necessarily mean the end of quality? Quality in Higher Education, 8(1), 71-79.

Marginson, S. (2002). Nation-building universities in a global environment: The case of Australia. Higher Education, 43, 409-428. 
This is an Author's Original Manuscript of an article published by Taylor \& Francis Group in Quality in Higher Education on 22 Sep 2014, available online: http://www.tandfonline.com/

Article DOI: $\quad 10.1080 / 13538322.2014 .957944$

Martin, L. (1994). Equity and General Performance Indicators in Higher Education. Canberra: Australian Government Publishing Service.

Martin, M. (2009). On the relationship of external quality assurance and equity: Can they converge on national policy agendas? Quality in Higher Education, 15(3), 251-262.

Monash University. (2008). Submission to the Review of Australian Higher Education Retrieved 10 February, 2014, from http://www.innovation.gov.au/highereducation/ResourcesAndPublications/ReviewO fAustralianHigherEducation/Pages/Submissions.aspx

National Commission of Audit. (2013). National Commission of Audit: terms of reference Retrieved 12 May 2014, 2004, from www.ncoa.gov.au/docs/NCA_TERMS_OF_REFERENCE.pdf

National Commission of Audit. (2014). National Commission of Audit: recommendations Retrieved 12 May 2014, 2004, from http://www.ncoa.gov.au/report/phaseone/recommendations.html

Pyne, C. (2014). Freeing universities to compete in a global education market Retrieved 29 April, 2014, from http://www.pyneonline.com.au/speeches/policy-exchange-speechfreeing-universities-to-compete-in-a-global-education-market

Rizvi, F., \& Lingard, B. (2011). Social equity and the assemblage of values in Australian higher education. Cambridge Journal of Education, 41(1), 5-22. doi: 10.1080/0305764x.2010.549459

Royal Melbourne Institute of Technology. (2013). Review of the demand-driven system of funding higher education Retrieved 10 February, 2014, from https://submissions.deewr.gov.au/Forms/demand-driven-fundingsystem/pages/index

Saarinen, T. (2010). What I talk about when I talk about quality. Quality in Higher Education, 16(1), 55-57.

Schuetze, H. G., \& Slowey, M. (2002). Participation and exclusion: A comparative analysis of non-traditional students and lifelong learners in higher education. Higher Education, 44(3/4), 309-327

Tam, M. (2001). Measuring quality and performance in higher education. Quality in Higher Education, 7(1), 47-54. doi: 10.1080/13538320120045076

Taylor, L. (2013, 1/7/2013). Rudd government to re-examine university funding cuts, The Guardian. Retrieved from http://www.theguardian.com/world/2013/jul/01/laborcapping-student-numbers-gonski?INTCMP=SRCH

The Australian. (2011). New demand driven system under debate Retrieved 23 January, 2014, from http://www.theaustralian.com.au/higher-education/legislation-fordemand-driven-system-in-parliament/story-e6frgcjx-1226135366954

Thompson-Whiteside, S. (2013). Assessing acadmeic standards in Australian higher education. In S. Marginson (Ed.), Tertiary education policy in Australia (pp. 39-58). Melbourne: Centre for the Study of Higher Education.

Trow, M. (1962). The democratization of higher education in America. European Journal of Sociology, 3(2), 231-262.

Trow, M. (1970). Reflections on the Transition from Mass to Universal Higher Education. Daedalus, 99(1), 1-42. doi: 10.2307/20023931

Trow, M. (1974). Problems in the Transition from Elite to Mass Higher Education. In OECD (Ed.), Policies for Higher Education (pp. 51). Paris: OECD. 
This is an Author's Original Manuscript of an article published by Taylor \& Francis Group in Quality in Higher Education on 22 Sep 2014, available online: http://www.tandfonline.com/

Article DOI: $\quad 10.1080 / 13538322.2014 .957944$

Trow, M. (2000). From Mass Higher Education to Universal Access: The American Advantage. Minerva, 37(4), 303-328. doi: 10.1023/A:1004708520977

Udam, M., \& Heidmets, M. (2013). Conflicting views on quality: Interpretations of 'a good university' by representatives of the state, the market and academia. Quality in Higher Education, 19(2), 210-224.

University of Melbourne. (2008). The University of Melbourne Submission: July 2008 Retrieved 10 February, 2014, from http://www.innovation.gov.au/highereducation/ResourcesAndPublications/ReviewO fAustralianHigherEducation/Pages/Submissions.aspx

University of Melbourne. (2013). Submission: Review of the Demand Driven Funding System Retrieved 10 February, 2014, from https://submissions.deewr.gov.au/Forms/demand-driven-fundingsystem/pages/index

University of Newcastle. (2008). Response to the Review of Australian Higher Education Discussion Paper Retrieved 10 February, 2014, from http://www.innovation.gov.au/highereducation/ResourcesAndPublications/ReviewO fAustralianHigherEducation/Pages/Submissions.aspx

University of Queensland. (2013). University of Queensland's submission to the Australian Government on the Review of the demand driven funding system Retrieved 10 February, 2014, from https://submissions.deewr.gov.au/Forms/demand-drivenfunding-system/pages/index

University of Southern Queensland. (2008). Response by the University of Southern Queensland to the Review of Australian Higher Education [Bradley Review] Discussion Paper, June 2008 Retrieved 10 February, 2014, from http://www.innovation.gov.au/highereducation/ResourcesAndPublications/ReviewO fAustralianHigherEducation/Pages/Submissions.aspx

University of Tasmania. (2008). Response to the Review of Australian Higher Education Discussion Paper Retrieved 10 February, 2014, from http://www.innovation.gov.au/highereducation/ResourcesAndPublications/ReviewO fAustralianHigherEducation/Pages/Submissions.aspx

University of Technology Sydney. (2008). Review of Australian Higher Education Submission Retrieved 10 February, 2014, from http://www.innovation.gov.au/highereducation/ResourcesAndPublications/ReviewO fAustralianHigherEducation/Pages/Submissions.aspx

University of Western Australia. (2008). UWA response to the Review of Australian Higher Education Discussion Paper Retrieved 10 February, 2014, from http://www.innovation.gov.au/highereducation/ResourcesAndPublications/ReviewO fAustralianHigherEducation/Pages/Submissions.aspx

University of Western Australia. (2013). UWA Submission to the Review of the Demand Driven System, December 2013 Retrieved 10 February, 2014, from https://submissions.deewr.gov.au/Forms/demand-driven-fundingsystem/pages/index

University of Western Sydney. (2013). Submission: Review of the Demand Driven Funding System Retrieved 10 February, 2014, from https://submissions.deewr.gov.au/Forms/demand-driven-fundingsystem/pages/index 
This is an Author's Original Manuscript of an article published by Taylor \& Francis Group in Quality in Higher Education on 22 Sep 2014, available online: http://www.tandfonline.com/

Article DOI: $\quad 10.1080 / 13538322.2014 .957944$

Vidovich, L., \& Currie, J. (1998). Changing accountability and autonomy at the 'coalface' of academic work in Australia. In J. Currie \& J. Newson (Eds.), Universities and Globalization: Critical perspectives. Thousand Oaks, CA: Sage.

Warn, J., \& Tranter, P. (2001). Measuring quality in higher education: a competency approach. Quality in Higher Education, 7(3), 191-198. doi: 10.1080/13538320120098078

Whiteford, G., Shah, M., \& Nair, C. (2013). Equity and excellence are not mutually exclusive: a discussion of academic standards in an era of widening participation. Quality Assurance in Education, 21(3), 299-310. 